\title{
UPAYA MENINGKATKAN HASIL BELAJAR PKN MENGGUNAKAN MODEL PEMBELAJARAN KOOPERATIF TIPE TUTOR SEBAYA PADA SISWA KELAS V.A SD NEGERI 149 PALEMBANG
}

\author{
Ida Afrianti \\ Guru SD Negeri 149 Palembang \\ afrianti@gmail.com
}

\begin{abstract}
ABSTRAK
Tujuan dari penelitian tindakan ini adalah mengetahui peningkatan hasil belajar PKn setelah diterapkannya model pembelajaran kooperatif Tutor Sebaya pada siswa kelas V.a SD Negeri 149 Palembang. Adapun Subjek dalam penelitian ini berjumlah 30 orang siswa. Penelitian ini menggunakan penelitian tindakan kelas (classroom action research) yang dilakukan sebanyak dua putaran. Setiap putaran terdiri dari empat tahap yaitu: rancangan, kegiatan dan pengamatan, refleksi, dan revisi. Data yang diperoleh berupa hasil tes formatif, lembar observasi kegiatan belajar mengajar. Dari hasil analis data diperoleh bahwa hasil belajar siswa mengalami peningkatan yang signifikan. peningkatan hasill belajar tersebut ditandai dengan peningkatan ketuntasan belajar siswa dalam setiap siklusnya, yaitu siklus mencapai kondisi awal $(36,67 \%)$, siklus I $(66,67 \%)$ dan siklus II $(86,67 \%)$. Dari hasil analisis data diperoleh dapat disimpulkan bahwa model pembelajaran kooperatif tipe tutor sebaya dapat berpengaruh positif terhadap peningkatan aktivitas serta hasil belajar siswa kelas V.a SD Negeri 149 Palembang.
\end{abstract}

Kata Kunci: Hasil Belajar,Tutor Sebaya, PKn

\begin{abstract}
The purpose of this action research was to determine the increase in civics learning outcomes after the implementation of the peer tutor cooperative learning model in class V.a SD Negeri 149 Palembang. The subjects in this study amounted to 30 students. This study used classroom action research which was conducted in two rounds. Each round consists of four stages, namely: design, activities and observations, reflection, and revision. The data obtained are in the form of formative test results, observation sheets of teaching and learning activities. From the results of the data analysis, it was found that student learning outcomes had increased significantly. The increase in learning outcomes is marked by an increase in student learning completeness in each cycle, namely the cycle reaches the initial condition (36.67\%), cycle I (66.67\%) and cycle II (86.67\%). From the results of data analysis, it can be concluded that the peertutor type of cooperative learning model can have a positive effect on increasing the activity and learning outcomes of class V.a SD Negeri 149 Palembang.
\end{abstract}

Keywords: Learning Outcomes, Peer Tutors, Civics 


\section{PENDAHULUAN}

Dalam dunia pendidikan guru memiliki peranan yang sangat penting dalam menentukan kuantitas dan kualitas pengajaran yang dilaksanakan. Oleh sebab itu, guru harus memikirkan dan membuat perencanaan secara seksama dalam meningkatkan hasil belajar bagi siswanya dan memperbaiki kualitas mengajarnya.

Hal ini menuntut perubahanperubahan dalam mengorganisasikan kelas, penggunaan metode mengajar, strategi belajar mengajar, maupun sikap dan karakteristik guru dalam mengelola proses belajar mengajar. Guru berperan sebagai pengelola proses belajar-mengajar, bertindak sebagai fasilitor yang berusaha menciptakan kondisi belajar mengajar yang efektif, sehingga memungkinkan proses belajar mengajar, mengembangkan bahan pelajaran dengan baik, dan meningkatkan kemampuan siswa untuk menyimak pelajaran dan menguasai tujuan-tujuan pendidikan yang harus mereka capai. Untuk memenuhi hal tersebut di atas, guru dituntut mampu mengelola proses belajar mengajar yang memberikan rangsangan kepada siswa, sehingga ia mau belajar karena siswalah subyek utama dalam belajar.

Pada pelajaran PKn dikelas V.a SD Negeri 149 Palembang metode mengajar yang digunakan masih menggunakan model lama yaitu metode ceramah yang disertai dengan tanya jawab. Namun penggunaan metode ini dianggap kurang tepat dalam belajar PKn karena siswa sudah terbiasa dengan metode ini sehingga kurangnya minat belajar siswa sehingga menurunkan hasil belajar siswa terhadap pelajaran PKn. Pemilihan metode mengajar dirasa penting untuk meningkatkan aktivitas belajar siswa sehingga meningkatkan hasil belajarnya. Untuk itu penulis ingin melakukan penelitian dengan menggunakan model pembelajaran kooperatif yang diharapkan dapat meningkatkan hasil belajar PKn pada siswa kelas V.a SD Negeri 149 Palembang .

Kegiatan belajar bersama dapat membantu memacu belajar aktif. Kegiatan belajar dan mengajar di kelas memang dapat menstimulasi belajar aktif. Namun kemampuan untuk mengajar melalui kegiatan kerjasana kelompok kecil akan memungkinkan 
untuk menggalakkan kegiatan belajar aktif dengan cara khusus. Apa yang didiskusikan siswa dengan temantemannya dan apa yang diajarkan siswa kepada teman-temannya memungkinkan mereka untuk memperoleh pemahaman dan penguasaan materi pelajaran.

Pembelajaran kooperatif lebih menekankan interaksi antar siswa. Dari sini siswa akan melakukan komunikasi aktif dengan sesama temannya. Dengan komunikasi tersebut diharapkan siswa dapat menguasai materi pelajaran dengan mudah karena siswa lebih mudah memahami penjelasan dari kawannya dibanding penjelasan dari guru, karena taraf pengetahuan serta pemikiran mereka lebih sejalan dan sepadan.

Salah satu model pembelajaran kooperatif adalah Tutor Sebaya. Model Pembelajaran Koperatif Tutor Sebaya merupakan pendekatan Cooperative Learning yang menekankan pada aktivitas dan interaksi diantara siswa untuk saling memotivasi dan saling membantu dalam menguasai materi pelajaran guna mencapai prestasi yang maksimal.

Berdasarkan latar belakang di atas, maka penulis merumuskan permasalahannya yaitu apakah model pembelajaran kooperatif Tipe Tutor sebaya dapat meningkatkan hasil belajar PKn pada siswa kelas V.a SD Negeri 149 Palembang?

Sesuai dengan permasalahan di atas, penelitian ini bertujuan untuk ingin mengetahui peningkatan hasil belajar PKn setelah diterapkannya model pembelajaran kooperatif Tutor Sebaya pada siswa kelas V.a SD Negeri 149 Palembang .

Menurut Hariyanto (2012 : 19)

belajar adalah suatu aktivitas atau suatu proses untuk memperoleh pengetahuan, meningkatkan keterampilan memperbaiki perilaku sikap dan mengkokohkan kepribadian.

Belajar adalah suatu proses usaha yang dilakukan seseorang untuk memperoleh suatu perubahan tingkah laku yang baru secara keseluruhan, sebagai hasil pengalamannya sendiri dalam interaksi dengan lingkungannya. (Slameto, 2010).

Belajar secara tradisional diartikan sebagaisesuatu yang lebih berorientasi pada pengembangan intelektual dan pengembangan otak dimana belajar ini merupakan usaha memperoleh sejumlah ilmu pengetahuan. Pandangan ini 
menyatakan knowledge is power yaitu barang siapa yang menguasai pengetahuan maka dia akan mendapat penguasaan.

Belajar secara modern mengenai belajer lebih berorientasi pada perubahan perilaku secara holistik dan integral. Dimana belajar ini merupakan proses perubahan tingkah laku mencakup aspek kognitif, afektif dan psikomotorik.

Belajar adalah suatu proses usaha yang dilakukan seseorang untuk memperoleh suatu perubahan tingkah laku yang baru secara keseluruhan, sebagai hasil pengalamannya sendiri dalam interaksi dengan lingkungannya.

Hasil belajar adalah kompetensi atau kemampuan tertentu baik kognitif, afektif maupun psikomotorik yang dicapai atau dikuasai peserta didik setelah mengikuti proses belajar mengajar.

Proses dalam pengertian disini merupakan interaksi semua komponen atau unsur yang terdapat dalam belajar mengajar yang satu sama lainnya saling berhubungan (inter independent) dalam ikatan untuk mencapai tujuan (Usman, 2000:5).

Belajar diartikan sebagai proses perubahan tingkah laku pada diri individu berkat adanya interaksi antara individu dengan lingkungannya. Hal ini sesuai dengan yang diutarakan Burton bahwa seseorang setelah mengalami proses belajar akan mengalami perubahan tingkah laku, baik aspek pengetahuannya, keterampilannya, maupun aspek sikapnya. Misalnya dari tidak bisa menjadi bisa, dari tidak mengerti menjadi mengerti. (dalam Usman, 2000:5).

Mengajar merupakan suatu perbuatan yang memerlukan tanggungjawab moral yang cukup berat. Mengajar pada prinsipnya membimbing siswa dalam kegiatan suatu usaha mengorganisasi lingkungan dalam hubungannya dengan anak didik dan bahan pengajaran yang menimbulkan proses belajar.

Proses belajar mengajar merupakan suatu inti dari proses pendidikan secara keseluruhan dengan guru sebagai pemegang peran utama. Proses belajar mengajar merupakan suatu proses yang mengandung serangkaian perbuatan guru dan siswa atas dasar hubungan timbal balik yang berlangsung dalam situasi edukatif untuk mencapai tujuan tertentu. 
Interaksi atau hubungan timbal balik antara guru dan siswa itu merupakan syarat utama bagi berlangsungnya proses belajar mengajar (Usman, 2000:4).

Belajar dapat membawa suatu perubahan pada individu yang belajar. Perubahan ini merupakan pengalaman tingkah laku dari yang kurang baik menjadi lebih baik. Pengalaman dalam belajar merupakan pengalaman yang dituju pada hasil yang akan dicapai siswa dalam proses belajar di sekolah. Menurut Poerwodarminto (1991:768), hasil belajar adalah hasil yang dicapai (dilakukan, dekerjakan), dalam hal ini hasil belajar merupakan hasil pekerjaan, hasil penciptaan oleh seseorang yang diperoleh dengan ketelitian kerja serta perjuangan yang membutuhkan pikiran.

Pembelajaran kooperatif adalah suatu pengajaran yang melibatkan siswa untuk bekerja dalam kelompokkelompok untuk menetapkan tujuan bersama. (Felder, 1994: 2).

Usman (2000: 8) menyebutkan bahwa pembelajaran kooperatif merupakan strategi pembelajaran dengan cara menempatkan siswa dalam kelompok-kelompok kecil yang memiliki kemampuan berbeda.
Sependapat dengan pernyataan

tersebut Hamalik (2002: 8) mengemukakan bahwa metode pembelajaran kooperatif memusatkan aktifitas di kelas pada siswa dengan cara pengelompokan siswa untuk bekerja sama dalam proses pembelajaran.

Pembelajaran kooperatif akan terlaksana dengan baik jika siswa memiliki keterampilan-keterampilan kooperatif. Keterampilan-keterampilan kooperatif yang perlu dimiliki siswa seperti diungkapkan Nur (2001: 25) adalah keterampilan kooperatif tingkat awal, tingkat menengah dan tingkat mahir.

Model pembelajaran adalah suatu pola atau langkah-langkah pembelajaran tertentu yang diterapkan agar tujuan atau kompetensi dari hasil belajar yang diharapkan akan cepat dapat dicapai dengan lebih efektif dan efisien. Ada beberapa model pembelajaran yang bisa digunakan guru, misalnya pembelajaran langsung, pembelajaran kooperatif, pembelajaran berbasis pada masalah, pembelajaran yang berbasis kompetensi, pembelajaran dengan pendekatan kontekstual, belajar tuntas, konstruktivisme dan sebagainya. 
Tutor sebaya merupakan bagian dari cooperative learning atau belajar bersama, Pembelajaran kooperatif merupakan sebuah kelompok strategi pengajaran yang melibatkan peserta didik bekerja secara berkolaborasi untuk mencapai tujuan bersama. Pembelajaran kooperatif disusun dalam sebuah usaha untuk meningkatkan partisipasi peserta didik, memfasilitasi peserta didik dengan pengalaman sikap kepemimpinan dan membuat keputusan dalam kelompok, serta memberikan kesempatan pada peserta didik untuk berinteraksi dan belajar bersama-sama yang berbeda latar belakangnya.

\section{Pembelajaran}

Kooperatif adalah sebuah grup kecil yang bekerjasama sebagai sebuah tim untuk memecahkan masalah (solve $a$ problem), melengkapi latihan (complete a task), atau untuk mencapai tujuan tertentu (accomplish a common goal). Pembelajaran kooperatif muncul dari konsep bahwa peserta didik akan lebih mudah menemukan dan memahami konsep yang sulit jika mereka saling berdiskusi dengan temannya. Kegiatan belajar bersama dapat membantu dan memacu belajar aktif. Dengan berkelompok peserta didik dapat berdiskusi dan mengajarkan kepada teman-temannya. Hal ini memungkinkan peserta didik memperoleh pemahaman dan penguasaan materi pelajaran.

Model pembelajaran cooperative learning tidak sama dengan sekedar belajar dalam kelompok. Ada unsurunsur dasar pembelajaran cooperative learning yang membedakannya dengan pembagian kelompok yang dilakukan asal-asalan. Pelaksanaan prosedur model cooperative learning dengan benar akan memungkinkan pendidik mengelola kelas dengan lebih efektif.

Roger dan david Johnson, yang dikutip oleh Agus Suprijono mengatakan bahwa tidak semua kerja sama bisa dianggap pembelajaran kooperatif. Untuk mencapai hasil yang maksimal, lima unsur model pembelajaran kooperatif harus diterapkan. Lima unsur tersebut adalah: Positive interdependence (saling ketergantungan).Persona responsibility (tanggung jawab perseorangan).Face to face promotive interaction (interaksi promotif). Interpersonal skill ( komunikasi antar anggota).Group processing ( pemrosesan kelompok / evaluasi). 
Menurut Abu Ahmadi dan Widodo Supriyono (2004) bahwa Tutor sebaya adalah siswa yang ditunjuk atau di tugaskan membantu teman yang mengalami kesulitan belajar, karena hubungan teman umumnya lebih dekat dibandingkan hubungan guru dengan siswa.

Sedangkan menurut Winataputra (1999) pengajaran dengan tutor sebaya adalah kegiatan belajar siswa dengan memanfaatkan teman sekelas yang mempunyai kemampuan lebih untuk membantu temannya dalam melaksanakan suatu kegiatan atau memahami suatu konsep.

Ada dua tipe peserta didik mengajar pesert didik lainnya, tipe pertama adalah pengajar dan pembelajar dari usia yang sama dan tipe kedua adalah pengajar yang lebih tua usianya dari pembelajar Muntasir dalam bukunya pengajaran terprogram mengemukakan bahwa tutor berfungsi sebagai tukang atau pelaksana mengajar, cara mengajarnya telah disiapkan secara khusus dan terperinci. Fungsi lainnya adalah dengan adanya tutor sebaya peserta didik yang kurang aktif menjadi aktif karena tidak malu lagi untuk bertanya dan mengeluarkan pendapat secara bebas, sebagaimana diungkapkan oleh M. Saleh Muntasir bahwa dengan pergaulan antara para tutor dengan murid-muridya mereka dapat mewujudkan apa yang terpendam dalam hatinya, dan khayalannya. Jadi, sistem pengajaran dengan tutor sebaya akan membantu peserta didik yang kurang mampu atau kurang cepat menerima pelajaran dari gurunya.

\section{METODE}

Penelitian ini merupakan jenis penelitian tindakan kelas (classroom action research), karena penelitian dilakukan untuk memecahkan masalah pembelajaran di kelas. Penelitian ini juga termasuk penelitian deskriptif, sebab menggambarkan bagaimana suatu teknik pembelajaran diterapkan dan bagaimana hasil yang diinginkan dapat dicapai.

Keempat bentuk penelitian tindakan di atas, ada persamaan dan perbedaannya. Menurut Oja dan Smulyan sebagaimana dikutip oleh Kasbolah, (dalam Sukidin, dkk. 2002:55), ciri-ciri dari setiap penelitian tergantung pada: (1) tujuan utamanya atau pada tekanannya, (2) tingkat kolaborasi antara pelaku peneliti dan peneliti dari luar, (3) proses yang digunakan dalam melakukan 
penelitian, dan (4) hubungan antara proyek dengan sekolah.

Dalam penelitian ini menggunakan bentuk guru sebagai peneliti, dimana guru sangat berperan sekali dalam proses penelitian tindakan kelas. Dalam bentuk ini, tujuan utama penelitian tindakan kelas ialah untuk meningkatkan praktik-praktik pembelajaran di kelas. Dalam kegiatan ini, guru terlibat langsung secara penuh dalam proses perencanaan, tindakan, observasi, dan refleksi. Kehadiran pihak lain dalam penelitian ini peranannya tidak dominan dan sangat kecil.

Sesuai dengan jenis penelitian yang dipilih, yaitu penelitian tindakan, maka penelitian ini menggunakan model penelitian tindakan dari Kemmis dan Taggart (1988:14), yaitu berbentuk spiral dari siklus yang satu ke siklus yang berikutnya. Setiap siklus meliputi planning (rencana), action (tindakan), observation (pengamatan), dan reflection (refleksi). Langkah pada siklus berikutnya adalah perncanaan yang sudah direvisi, tindakan, pengamatan, dan refleksi. Sebelum masuk pada siklus 1 dilakukan tindakan pendahuluan yang berupa identifikasi permasalahan.
Penjelasan prosedur penelitian adalah: Rancangan/perencana awal, sebelum mengadakan penelitian peneliti menyusun rumusan masalah, tujuan dan membuat rencana tindakan, termasuk di dalamnya instrumen penelitian dan perangkat pembelajaran. Pelaksanaan dan pengamatan, meliputi tindakan yang dilakukan oleh peneliti sebagai upaya membangun pemahaman konsep siswa serta mengamati hasil atau dampak dari diterapkannya model pembelajaran kooperatif tutor sebaya.Refleksi, peneliti mengkaji, melihat dan mempertimbangkan hasil atau dampak dari tindakan yang dilakukan berdasarkan lembar pengamatan yang diisi oleh pengamat.

Rancangan/rencana yang direvisi, berdasarkan hasil refleksi dari pengamat membuat rangcangan yang direvisi untuk dilaksanakan pada siklus berikutnya.

Tempat penelitian adalah tempat yang digunakan dalam melakukan penelitian untuk memperoleh data yang diinginkan. Penelitian ini bertempat di SD Negeri 149 Palembang Tahun Pelajaran 2017/2018. Waktu penelitian adalah waktu berlangsungnya penelitian atau 
saat penelitian ini dilangsungkan. Penelitian ini dilaksanakan pada bulan Agustus sampai dengan Oktober 2017.

Subyek penelitian adalah siswa-

siswi kelas V.a SD Negeri 149 Palembang pada pokok bahasan menjelaskan pentingnya keutuhan Negara Kesatuan Republik Indonesia.

Persentase ketuntasan klasikal hasil belajar peserta didik didalam penelitian ini $85 \%$ peserta didik yang telah tuntas mengikuti pembelajaran PKn. Penelitian ini dilaksanakan melalui 5 tahap, yaitu,(1) tahap perencanaan,(2) tahap persiapan, dan (3) tahap pelaksanaan, (4) tahap pengolahan data, dan (5) penyusunan laporan.

\section{PEMBAHASAN}

\section{Pra Siklus}

Sebelum dilakukan penelitian tindakan perbaikan, di awal peneliti sebagai guru mengajar mata pelajaran PKn dengan menggunakan metode ceramah, dimana guru sebagai pusat pembelajaran yang disertai dengan proses tanya jawab dengan siswa. Pada kondisi ini terlihat para siswa kurang bersemangat dalam belajar, sehingga masih terlihat siswa yang tidak memperhatikan ketika guru menerangkan di depan kelas dengan mengobrol dengan sesama siswa lainnya. Hal ini berdampak pada hasil belajar siswa yang rendah, yang dapat di lihat pada tabel di bawah ini:

\section{Tabel 1. Nilai Tes Formatif} Kondisi Awal

\begin{tabular}{|c|c|c|}
\hline \multicolumn{3}{|l|}{ Nilai Rata } \\
\hline Rata & $=$ & $\mathbf{5 9 . 5 0}$ \\
\hline Jumlah Nilai & $=$ & 1785 \\
\hline Jumlah Nilai & & \\
\hline Maksimal ideal & $=$ & 3000 \\
\hline $\begin{array}{l}\text { Jumlah siswa yang } \\
\text { belum tuntas }\end{array}$ & $=$ & 19 \\
\hline $\begin{array}{l}\text { Jumlah siswa yang } \\
\text { tuntas }\end{array}$ & $=$ & 11 \\
\hline $\begin{array}{l}\text { Persentase Belum } \\
\text { tuntas }\end{array}$ & & \\
\hline Persentase ketuntasan & $=$ & 36.67 \\
\hline Klasikal & & $\begin{array}{l}\text { Belum } \\
\text { Tuntas }\end{array}$ \\
\hline
\end{tabular}

Berdasarkan tabel di atas diketahui bahwa persentase ketuntasan untuk mata pelajaran PKn pada siswa kelas V.a SD Negeri 149 Palembang pada kondisi awal pembelajaran adalah sebesar $36.67 \%$. Hal ini berarti, jika di lihat dari segi kriteria ketuntasan klasikal belajar mata pelajaran PKn sebesar $85 \%$ artinya hasil ini menunjukkan bahwa ketuntasan belajar masih sangat rendah. Nilai rata - rata tes formatif adalah 59.50. Tabel di atas menunjukkan sebanyak 11 siswa atau sebesar $36.67 \%$ siswa kelas V.a di SD Negeri 149 Palembang yang tuntas untuk mata pelajaran PKn 
sedangkan sisanya sebanyak 19 orang belum tuntas.

Berdasarkan hasil penjelasan penilaian di atas, peneliti menyimpulkan bahwa siswa kelas V.a SD Negeri 149 Palembang tingkat ketuntasan belajar untuk mata pelajaran PKn belum dikatakan baik. Hal ini dikarenakan belum mencapai kriteria ketuntasan hasil belajar yang ditetapkan yaitu minimal sebanyak $85 \%$ siswa tuntas dalam proses pembelajaran PKn.

Untuk itu peneliti dengan di bantu teman sejawat berupaya melakukan tindakan perbaikan guna meningkatkan hasil belajar PKn dengan mencari metode pembelajaran yang dianggap tepat. Berdasarkan hasil diskusi kecil dengan teman sejawat maka di tentukanlah model pembelajaran kooperatif tipe Tutor sebaya yang akan digunakan dalam proses tindakan perbaikan pembelajaran PKn yang diharapkan dapat meningkatkan hasil belajar Pkn yang pelaksanaannya akan dilaksanakan dalam 2 siklus.

\section{Siklus I}

Pelaksanaan kegiatan belajar mengajar untuk siklus I dilaksanakan dalam dua kali pertemuan. Pertemuan pertama dilaksanakan 25 Agustus 2017 dan pertemuan kedua dilaksanakan pada tanggal 1 September 2017 di kelas V.a SD Negeri 149 Palembang yang berjumlah 30 peserta didik. Dalam penelitian ini akan di bantu oleh teman sejawat yang bertugas sebagai observer yang bernama Sali Agustini, S.Pd.SD.

Pengamatan dilaksanakan bersamaan dengan pelaksanaan dengan pelaksanaan belajar mengajar. Selama siklus I berlangsung, observer telah melakukan pengamatan terhadap keaktifan belajar siswa dalam kegiatan pembelajaran. Berdasarkan tabel di atas tampak bahwa aktivitas guru pada siklus I adalah Memberikan umpan balik yaitu 3 (Cukup Baik). Aktivitas lain yang presentasinya cukup besar adalah membimbing siswa merangkum pelajaran yaitu 3 (Cukup Baik), kemudian aktivitas guru adalah menyampaikan tujuan pelajaran mendapatkan nilai 2 (Kurang), untuk motivasi siswa mendapatkan nilai 2 (Kurang), membimbing dan mengamati siswa dalam menemukan konsep yaitu mendapatkan nilai 2 (Kurang). Aktivitas guru menyampaikan materi/ langkah-langkah/strategi mendapatkan nilai 2 (Kurang), aktivitas mengaitkan 
materi sebelumnya mendapatkan nilai 2 (Kurang). Secara keseluruhan aktivitas guru mendapatkan nilai 20 dengan persentase $55.56 \%$ dengan kriteri Cukup Baik.

Hasil pengamatan terhadap keaktifan belajar siswa pada siklus I memperlihatkan temuan, bahwa aspek pengamatan

Mendengarkan/ memperhatikan penjelasan guru mendapatkan angka 62,50\% (Cukup Baik), pengamatan membaca buku mendapatkan angka $67,50 \%$,di lanjutkan dengan Bekerja dengan sesama anggota kelompok mendapatkan angka $65.83 \%$, kegiatan siswa Diskusi antar siswa/ antara siswa dengan guru 58,33\%.

Kemudian di susul menyajikan hasil pembelajaran $66,67 \%$, aktivitas siswa Menyajikan/ menanggapi pertanyaan/ ide mendapatkan angka $64,17 \%$, kemudian Menulis yang relevan dengan KBM mendapatkan nilai $\quad 64,17 \%$. Kemudian aktivitas siswa Merangkum pembelajaran mendapatkan nilai $\quad 66.67 \%$ dan mengerjakan tes evaluasi mendapatkan nilai 64,17 .

Berdasarkan uraian di atas aktivitas yang mendapatkan nilai yang rendah adalah mendengarkan/ memperhatikan penjelasan guru 62.50 $\%$ (Cukup Baik) dan Aktivitas diskusi antar siswa/ antara siswa dengan guru $58.33 \%$ (Cukup Baik).

Pada akhir proses belajar pertemuan kedua siswa diberi tes formatif I dengan tujuan untuk mengetahui tingkat keberhasilan siswa dalam proses belajar mengajar yang telah dilakukan. Hasil belajar siklus I dapat dilihat pada table dibawah ;

Tabel 2. Tes Formatif Siklus I

\begin{tabular}{|ll|}
\hline Jumlah Nilai & $=2065$ \\
Jumlah Nilai Maksimal ideal & $=3000$ \\
Rata-rata Nilai Tercapai & $=68.83$ \\
Jumlah siswa yang belum tuntas & $=10$ \\
Jumlah siswa yang tuntas & $=20$ \\
Persentase Belum tuntas & $=33.33$ \\
Persentase ketuntasan & $=66.67$ \\
Klasikal & $=$ Belum Tuntas
\end{tabular}

Dari tabel di atas dapat dijelaskan bahwa dengan menerapkan model pembelajaran kooperatif Tutor Sebaya diperoleh nilai rata-rata hasil belajar siswa adalah 68.33 dan ketuntasan belajar mencapai $66,67 \%$ atau ada 20 siswa dari 30 siswa sudah tuntas belajar. Siswa yang mendapatkan nilai kurang dari 70 sebanyak 10 siswa dengan persentase $33.33 \%$.Hasil tersebut menunjukkan bahwa pada siklus pertama secara klasikal siswa 
belum tuntas belajar, karena siswa yang memperoleh nilai $\geq 70$ hanya sebesar 66,67\% lebih kecil dari presentase ketuntasan yang dikehendaki yaitu sebesar $85 \%$. Hal ini disebabkan karena siswa masih merasa baru dan belum mengerti apa yang dimaksudkan dan digunakan guru dengan menerapkan model pembelajaran kooperatif Tutor Sebaya.

Dalam pelaksanaan kegiatan belajar mengajar diperoleh informasi dari hasil pengamatan sebagai berikut :Guru masih kurang dalam memotivasi siswa sehingga hasil belajar menjadi rendah.Dalam menjalankan langkah langkah pembelajaran masih kurang.

Guru masih kurang dalam membimbing siswa dalam menemukan konsep.

Pelaksanaan kegiatan belajar mengajar pada siklus I ini masih terdapat kekurangan, sehingga perlu adanya revisi untuk ilakukan pada siklus berikutnya. Diharapkan guru lebih pandai dalam memovitasi siswa dalam pembelajaran.Guru lebih mempelajari lagi langkah langkah model pembelajaran. Guru di harapkan memaksimalkan membimbing siswa yang kurang dalam pemahaman menerima materi.Guru lebih cermat dalam menyampaikan tujuan pembelajaran.

\section{Siklus II}

Pelaksanaan kegiatan belajar mengajar untuk siklus II dilaksanakan dalam dua kali pertemuan yakni pertemuan pertama pada tanggal 15 september 2017 dan pertemuan kedua pada tanggal 22 September 2017 di kelas V.a SD Negeri 149 Palembang dengan jumlah siswa 30 siswa. Dalam hal ini peneliti bertindak sebagai pengajar, sedangkan yang bertindak sebagi observer yang akan membantu proses belajar mengajar adalah seorang guru PKn dan wali kelas V.a SD Negeri 149 Palembang. Adapun proses belajar mengajar mengacu pada rencana pelajaran dengan memperhatikan revisi pada siklus I, sehingga kesalahan atau kekurangan pada siklus I tidak terulang lagi pada siklus II. Pengamatan (observasi) dilaksanakan bersamaan dengan pelaksanaan belajar mengajar.

Pada proses belajar mengajar pertemuan kedua, observer melaksanakan pengamatan terhadap siswa dengan tujuan untuk mengetahui tingkat keberhasilan siswa dalam proses belajar mengajar yang telah dilakukan. 
Selama siklus II berlangsung, mendapatkan angka 70,83\% ,di observer telah melakukan pengamatan lanjutkan dengan Bekerja dengan terhadap keaktifan belajar siswa dalam sesama kelompok kegiatan pembelajaran. Berdasarkan mendapatkan angka $70.83 \%$, kegiatan tabel di atas tampak bahwa aktivitas siswa Diskusi antar siswa/ antara siswa guru pada siklus I adalah Memberikan dengan guru 73,33\%.

umpan balik yaitu 3 (Cukup Baik).

Kemudian di susul menyajikan Aktivitas lain yang presentasinya hasil pembelajaran 77,33\%, aktivitas cukup besar adalah membimbing siswa merangkum pelajaran yaitu 3 (Cukup Baik), kemudian aktivitas guru adalah menyampaikan tujuan pelajaran mendapatkan nilai 4 (Baik), untuk siswa Menyajikan/ menanggapi pertanyaan/ ide mendapatkan angka $72,50 \%$, kemudian Menulis yang relevan dengan KBM mendapatkan nilai $75.83 \%$. Kemudian aktivitas motivasi siswa mendapatkan nilai 3 siswa Merangkum pembelajaran (Cukup Baik), membimbing dan mendapatkan nilai $80 \%$ dan mengamati siswa dalam menemukan mengerjakan tes evaluasi mendapatkan konsep yaitu mendapatkan nilai 3 nilai 72.50 .

(Baik). Aktivitas guru menyampaikan

Berdasarkan uraian di atas materi/ langkah-langkah/ strategi aktivitas yang mendapatkan nilai yang mendapatkan nilai 3 (Baik), aktivitas rendah adalah siswa yang membaca mengaitkan materi sebelumnya buku dengan $70.83 \%$ ( Baik) dan mendapatkan nilai 4 (Baik). Secara Bekerja dengan sesama anggota keseluruhan aktivitas guru kelompok dengan nilai 58.33\% ( Baik). mendapatkan nilai 30 dengan Kedua aspek kedua ini merupakan nilai persentase $83 \%$ dengan kriteri Baik. yang rendah jika di bandingkan dengan Hasil pengamatan terhadap aspek yang lain. Berikutnya adalah keaktifan belajar siswa pada siklus II rekapitulasi hasil tes formatif siklus II memperlihatkan temuan, bahwa aspek dapat terlihat pada tabel berikut : pengamatan mendengarkan/ memperhatikan penjelasan guru mendapatkan angka 82,50 \%, pengamatan membaca buku 
Tabel 2. Nilai Tes Siklus II

\begin{tabular}{|ll|}
\hline Jumlah Nilai & $=2240$ \\
Jumlah Nilai Maksimal ideal & $=3000$ \\
Rata-rata Nilai Tercapai & $=74.67$ \\
Jumlah siswa yang belum tuntas & $=4$ \\
Jumlah siswa yang tuntas & $=26$ \\
Persentase Belum tuntas & $=13.33$ \\
Persentase ketuntasan & $=86.67$ \\
Klasikal & $=$ Tuntas
\end{tabular}

Dari tabel diatas diperoleh nilai rata-rata hasil belajar siswa adalah 74.67 dan ketuntasan belajar mencapai $86,67 \%$ atau ada 26 siswa dari 30 siswa sudah tuntas belajar.Hasil ini menunjukkan bahwa pada siklus II ini ketuntasan belajar secara klasikal telah mengalami peningkatan lebih baik dari siklus I. Adanya peningkatan hasil belajar siswa ini karena setelah guru menginformasikan bahwa setiap akhir pelajaran akan selalu diadakan tes sehingga pada pertemuan berikutnya siswa lebih termotivasi untuk belajar. Selain itu siswa juga sudah mulai mengerti apa yang dimaksudkan dan diinginkan guru dengan menerapkan model pembelajaran kooperatif Tutor Sebaya.

Dalam pelaksanaan kegiatan belajar diperoleh informasi dari hasil pengamatan sebagai berikut : Guru sudah berhasil dalam memotivasi siswa sehingga hasil belajar menjadi meningkat.

Dalam menjalankan langkah langkah pembelajaran guru sudah meningkat Guru sudah maksimal menguasai suasana kelas sehingga tidak kaku proses pembelajaranya.

Secara keseluruhan aktivitas guru,aktivitas siswa dan hasil belajar sudah meningkat jika di bandingkan dengan siklus I. Maka dari itu penelitian ini di cukupkan pada siklus II dan tidak perlu dilanjutkan pada siklus berikut nya.

Pelaksanan kegiatan belajar pada Siklus II ketuntasan telah tercapai namun masih terdapat sedikit kekurangan . Pada siklus II guru telah menerapkan pembelajaran dengan model kooperatif Tutor Sebaya dengan baik dan dilihat dari aktivitas siswa serta hasil belajar siswa pelaksanaan proses belajar mengajar sudah berjalan dengan baik. Maka tidak diperlukan revisi terlalu banyak, tetapi yang perlu diperhatikan untuk tindakan selanjutnya adalah memaksimalkan dan mepertahankan apa yang telah ada dengan tujuan agar pada pelaksanaan proses belajar mengajar selanjutnya penerapan pembelajaran dengan 
pembelajaran kooperatif model Tutor Sebaya dapat meningkatkan proses belajar mengajar sehingga tujuan pembelajaran dapat tercapai.

\section{Pembahasan}

Melalui hasil penelitian ini menunjukkan bahwa model pembelajaran kooperatif Tutor Sebaya memiliki dampak positif dalam meningkatkan hasil belajar siswa. Hal ini dapat dilihat dari semakin mantapnya pemahaman siswa terhadap materi yang disampaikan guru. Ketuntasan hasil belajar telah tercapai yaitu masing - masing pada pra Siklus $(36,67 \%)$ siklus I $(66,67 \%)$, dan siklus II $(86,67 \%)$. Pada siklus II ketuntasan belajar siswa secara klasikal telah tercapai. Pada siklus II ketuntasan belajar siswa secara klasikal telah tercapai kemampuan guru dalam mengelola pembelajaran. Peningkatan hasil belajar siswa dapat dilihat pada tabel dibawah ini:

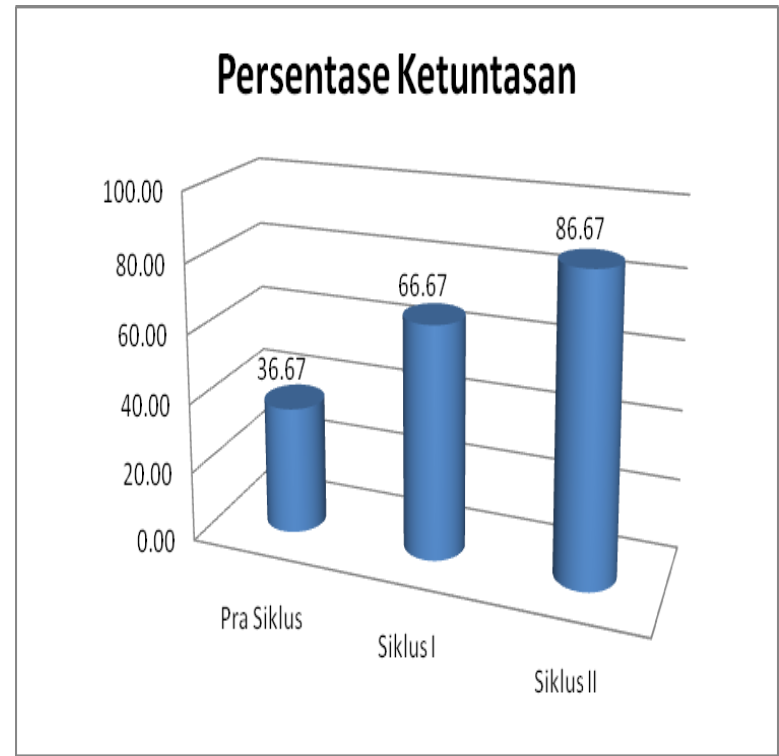

\section{Grafik 1. Grafik Pencapaian KKM} Klasikal

Berdasarkan analisis data, diperoleh aktifitas siswa dalam proses belajar mengajar dengan menerapkan model pembelajaran kooperatif Tutor Sebaya dalam setiap siklus mengalami peningkatan. Hal ini berdampak positif terhadap hasil belajar peserta didik yaitu dapat ditunjukkan dengan meningkatnya nilai rata-rata siswa pada setiap siklus yang terus mengalami peningkatan.

Sedangkan untuk aktifitas guru selama pembelajaran telah melaksanakan langkah-langkah kegiatan belajar mengajar dan menerapkan pengajaran konstektual model pengajaran dengan baik. Hal ini terlihat dari aktivitas guru yang muncul, diantaranya aktivitas 
membimbing dan mengamati peserta memiliki dampak positif dalam didik dalam menemukan konsep, meningkatkan hasil belajar peserta menjelaskan materi yang sulit, didik yang ditandai dengan memberi umpan balik/ evaluasi/ tanya peningkatan ketuntasan belajar siswa jawab dimana presentase untuk dalam setiap siklus, yaitu Pra Siklus aktivitas di atas cukup besar. $(36,67 \%)$, siklus I $(66,67 \%)$, siklus II Berdasakan analisis data, (86,67\%).Model pembelajaran diperoleh aktifitas peserta didik dalam kooperatif Tutor Sebaya dapat proses pembelajaran PKn melalui menjadikan peserta didik merasa metode pembelajaran tutor sebaya yang dirinya mendapat perhatian dan paling dominan adalah mendengarkan kesempatan untuk menyampaikan dan memperhatikan penjelasan guru pendapat, gagasan, ide, dan pertanyaan. ,merangkurm pembelajaran,bekerja Peserta didik dapat bekerja secara dengan sesama anggota kelompok, mandiri maupun kelompok, serta mendengarkan/ memperhatikan mampu mempertanggung jawabkan penjelasan guru dan diskusi antar tugas individu maupun kelompok. peserta didik /antara peserta didik Penerapan model pembelajaran dengan guru. Hasil penilaian lebih kooperatif Tutor Sebaya mempunyai meningkakat jika di bandingkan pengaruh positif, yaitu dapat dengan siklus I. Jadi dapat dikatakan meningkatkan aktivitas belajar peserta bahwa aktifitas peserta didik didik. dikategorikan aktif.

Dari hasil penelitian yang KESIMPULAN

Berdasarkan hasil penelitian diperoleh dari uraian sebelum agar proses belajar mengajar PKn lebih yang telah dipaparkan selama dua efektif dan lebih memberikan hasil siklus, hasil seluruh pembahasan serta analisis yang telah dilakukan dapat yang optimal bagi siswa, maka disampaikan saran sebagai berikut : disimpulkan bahwa Model Untuk melaksanakan model pembelajaran kooperatif Tutor Sebaya dapat meningkatkan kualitas pembelajaran kooperatif Tutor sebaya pembelajaran PKn. Metode memerlukan persiapan yang cukup pembelajaran kooperatif Tutor Sebaya matang, sehingga guru harus mampu menentukan atau memilih topik yang 
benar-benar bisa diterapkan dengan Model pembelajaran kooperatif tutor sebaya dalam proses belajar mengajar sehingga memperoleh hasil yang optimal.

\section{DAFTAR PUSTAKA}

Abu Ahmadi dan Widodo S.2004. Psikologi Belajar Edisi Revisi.Jakarta: PT Rineka Cipta.

Felder, Richad M. 1994. Cooperative Learning In The Technical Corse, (online), (Pcllld।My\% DocumentlCoop \% 20 Report.

Hamalik, Oemar. 2002. Psikologi Belajar dan Mengajar. Bandung: Sinar Baru Algesindo Hariyanto, Suryono. 2012. Belajar dan Pembelajaran. Bandung : PT. Remaja Rosdakarya. Hal 19.

Kemmis, S. dan Mc. Taggart, R. 1988. The Action Research Planner. Victoria Dearcin University Press.

Nur,Moh. 2001. Pemotivasian Siswa Untuk Belajar. Surabaya. University Press.Universitas Negeri Surabaya.

Poerwodarminto, W. J. S. 1991.Kamus Umum Bahasa Indonesia. Jakarta : Balai Pustaka.
Slameto. 2010. Belajar dan Faktor faktor yang mempengaruhinya. Jakarta : Rineka Cipta. Hal 2

Sukidin dkk. 2002. Manajemen Penelitian Tindakan Kelas. Surabaya: Insane Cendekia.

Usman, Moh. Uzer. 2000. Menjadi Guru Profesional. Bandung: Remaja Rosdakarya.

Winataputra,Udin, S.1999. Pendekatan Pembelajaran Kelas Rangkap.Jakarta:Departemen Pendidikan dan Kebudayaan. 